\title{
Pengaruh Teknologi Informasi dan Komitmen Pelayanan terhadap Good Governance di Jajaran Pemerintah Kota Banda Aceh
}

\author{
Irma Farnita ${ }^{1}$, Rahmad Junaidi $^{2}$ \\ 1,2 STMIK Indonesia Banda Aceh, Indonesia.
}

\begin{abstract}
Abstrak. Fokus utama penelitian ini menganalisis pengarub teknologi informasi dan komitmen pelayanan terhadap implementasi prinsip-prinsip good government governance (GGG) serta dampaknya pada kinerja pegawai. Penelitian dilakukan pada sejumlah SKPD dilingkungan pemerintah kota Banda Aceh. Pengumpulan data melalui penyebaran kuesioner kepada 170 orang pegawai. Kemudian data dianalisis menggunakan statistik. multivariat structural equation modelling. Penelitian menemukan adanya pengarub positif dan signifikan teknologi informasi dan komitmen pelayanan terbadap implementasi GGG dan kinerja pegawai. Eksistensi implementasi GGG tidak hanya berdampak positif terbadap peningkatan kinerja, tetapi juga memediasi pengarub teknologi informasi dan komitmen pelayanan terhadap kinerja pegawai dilingkungan pemerintah kota Banda Aceh.
\end{abstract}

Kata kunci: Kinerja Pegawai, Implementasi GGG, teknologi informasi dan komitmen pelayanan.

\begin{abstract}
The main focus of this research is to analyze the effect of information technology and service commitment to the implementation of the principles of good government governance (GGG) and its impact on employee performance. The research was conducted at a number of the local government work unit (SKPD) within the Banda Aceh government. Collecting data through distributing questionnaires to 170 employees. Then the data were analyzed using multivariate statistics structural equation modeling. The study found a positive and significant effect of information technology and service commitment on GGG implementation and employee performance. The existence of GGG implementation not only has a positive impact on performance improvement, but also mediates the effect of information technology and service commitment on employee performance.
\end{abstract}

Keywords: Employee's performance, GGG implementation, information technology, services commitment, structural equation modelling. 


\section{Pendahuluan}

Implementasi prinsip-prinsip good government governance (GGG) dalam instansi pemerintah merupakan suatu keharusan dalam penyelenggaran layanan publik (Dwiyanto, 2016). Karena itu diperlukan adanya upaya peningkatan kinerja aparatur pemerintah. Hal ini sangat beralasan mengingat faktor manusia merupakan sumber daya utama dalam mendukung kegiatan operasional instansi pemerintah. Kinerja pegawai merefleksikan hasil kerja yang dicapai seseorang atau sekelompok pegawai dalam melaksanakan pekerjaan yang dibebankan (Rivai \& Sagala, 2009: 309). Selain kinerja pegawai, faktor lain yang secara empiris dapat mempengaruhi penerapan prinsip-prinsip GGG adalah teknologi informasi dan komitmen pelayanan. Teknologi informasi dapat didefinisikan sebagai pondasi dari kapabilitas teknologi informasi, yang mencakup seluruh instansi termasuk instansi pemerintah dalam bentuk pelayanan yang dapat dipercaya dan disediakan oleh kelompok sistem informasi (Weill et al., 2016). Ketersediaan teknologi informasi tidak hanya dapat berpengaruh pada kelancaran tugas pegawai, tetapi juga dapat meningkatkan kinerja pegawai dalam bekerja dan pada gilirannya berdampak pada upaya penerapan prinsipprinsip GGG.

Selanjutnya komitmen pelayanan dalam diri seseorang pegawai merefleksikan kemauan yang kuat untuk memberikan pelayanan sesuai dengan tanggung jawab yang diberikan kepada pegawai tersebut (Ali \& Tang, 2016). Komitmen pelayanan berarti perjanjian untuk melakukan sesuatu baik dengan diri sendiri, orang lain atau juga suatu organisasi. Komitmen pelayanan sebagai kebulatan hati mengabdikan diri dengan segenap hati, pikiran, kekuatan demi unsur janji kesetiaan bahwa apa yang diputuskan itu merupakan tekad atau kebulatan hati seseorang dalam melakukan pelayanan (Barna, 2010). Adanya komitmen yang kuat dalam diri pegawai mendorong munculnya keinginan sukses dalam melaksanakan setiap tugas yang pada gilirannya berdampak positif pada capaian hasil kerja mereka. Kondisi ini juga akan berdampak pada upaya penerapan prinsipprinsip GGG pada instansi pemerintah. Hasil survei awal yang dilakukan pada sejumlah
SKPD di kota Banda Aceh mengindikasikan bahwa implementasi prinsip GGG dipersepsikan beragam oleh para pegawainya. Selain itu, komitmen mereka dalam mendukung kegiatan operasional instansi guna menyenlenggarakan pelayanan publik juga relatif berbeda satu sama lain. Di satu sisi terdapat pegawai dengan komitmen pelayanan relatif baik dan disisi lain juga ada diantara mereka dengan komitmen pelayanan relatif tinggi. Penilaian pegawai terhadap eksistensi teknologi informasi yang pada instansi tempat mereka bekerja juga relatif berbeda satu sama lain. Sebagaimana dijelaskan sebelumnya, penerapan GGG pada instansi pemerintah terkait dengan kinerja pegawai, ketersediaan teknologi informasi dan komitmen pelayanan dalam diri pegawai. Karena itu, penelitian ini menganalisis penerapan prinsip GGG dan kinerja pegawai dilingkungan pemerintah Kota Banda Aceh dengan menggunakan tiga variabel tersebut sebagai predictor variable. Dalam hal ini, kinerja pegawai juga ditempatkan sebagai intervening variabel antara penerapan prinsip GGG di satu sisi dengan ketersediaan teknologi informasi dan komitmen pelayanan di sisi lain.

Mengacu pada latar belakang yang telah dijelaskan sebelumnya, penelitian ini bertujuan untuk menganalisis eksistensi teknologi informasi dan komitmen pelayanan terhadap kinerja pegawai dan penerapan prinsip good governance pada SKPD dilingkungan Pemerintah Kota Banda Aceh.

\section{Literature Review}

\section{Keterkaitan antara Penerapan Prinsip GGG dan Kinerja Pegawai}

Penerapan prinsip GGG pada instansi pemerintah tidak hanya diharapkan mampu memberikan manfaat bagi masyarakat sebagai pengguna layanan publik, tetapi juga mampu mendorong pegawai untuk bekerja lebih baik. Sebagaimana dijelaskan sebelumnya, implementasi GGG memiliki beberapa prinsip dasar yang harus dipenuhi di antaranya responsiveness, consensus orientation, efficiency and effectiveness, accountability dan strategic visión. Prinsip responsiveness menyatakan bahwa lembaga pemerintah harus cepat dan tanggap melayani stakeholdernya terutama masyarakat. Selanjutnya prinsip consensus 
orientation mengharuskan bahwa kegiatan yang dilakukan berorientasi pada kepentingan masyarakat luas. Prinsip efficiency and effectiveness berarti bahwa pengelolaan sumber daya publik dilakukan secara berdaya guna (efisien) dan berhasil guna (efektif), selanjutnya prinsip accountability berkaitan dengan adanya pertanggungjawaban kepada publik atas aktivitas yang dilakukan. Terakhir prinsip strategic vision mengisyaratkan bawah setiap penyelenggara pemerintahan dan masyarakat harus memiliki visi jauh ke depan. Implementasi prinsip-prinsip GGG tersebut dalam instansi pemerintah mengharuskan setiap pegawai bekerja lebih baik. Mereka harus mampu bekerja secara efektif dan efisien, meningkatkan kualitas pelayanan yang diberikan, serta mampu menjamin terwujudnya akuntabilitas kinerja berhubungan dengan seluruh kegiatan yang mereka lakukan. Secara empiris, adanya keterkaitan antara penerapan prinsip GGG dengan kinerja pegawai dibuktikan oleh Trakulmututa \& Chaijareonwattana (2013) dalam penelitian mereka tentang pencapaian GGG di Thailand. Mereka menyimpulkan bahwa terdapat hubungan yang sangat erat antara penerapan prinsip GGG dengan kinerja pegawai.

\section{Keterkaitan antara Teknologi Informasi dan Penerapan prinsip GGG}

Keberadaan teknologi informasi juga dapat berpengaruh terhadap implementasi prinsip GGG. Karena upaya penggunaan teknologi informasi dalam pelaksanaan pekerjaan dapat mendukung transparansi, akurasi serta efektifitas pekerjaan. Ketiga hal tersebut merupakan bagian terpenting dari implementasi GGG pada instansi pemerintah. Adanya pengaruh teknologi informasi terhadap implementasi GGG sudah dibuktikan oleh Trakulmututa \& Chaijareonwattana (2013) dalam penelitian mereka di Thailan yang menyimpulkan bahwa pencapaian good governance pada instansi pemerintah dipengaruhi oleh beberapa faktor di antaranya teknologi informasi.

\section{Keterkaitan antara Komitmen Pelayanan dan Penerapan GGG}

Implementasi prinsip GGG membutuhkan adanya komitmen pegawai. Hal ini disebabkan pegawai merupakan sumber daya utama instansi yang ikut berperan aktif dalam menjalankan seluruh aktivitas instansi. Implementasi prinsipprinsip GGG pada dasarnya diharapkan mampu meningkatkan kualitas pelayanan publik guna memenuhi kebutuhan masyarakat. Temuan penelitian empiris yang dilakukan oleh Trakulmututa \& Chaijareonwattana (2013) di Thailan membuktikan bahwa salah satu faktor yang menentukan keberhasilan penerapan GGG adalah manajemen SDM dan komitmen pegawai dalam melaksanakan tugas mereka.

\section{Keterkaitan antara Teknologi Informasi dan Kinerja Pegawai}

Kinerja pegawai sangat penting artinya bagi setiap organisasi terutama yang berkaitan dengan pelayanan publik (Amri, 2015). Guna meningkatkan kinerja pegawai, keberadaan teknologi informasi merupakan suatu hal yang sangat penting, tidak hanya mempermudah pekerjaan administrasi, tetapi memberikan banyak manfaat bagi komunikasi dan koordinasi dalam lingkungan kerja (Ahmad \& Wali, 2019). Ketersediaan teknologi informasi seperti komputer dengan perangkat lunaknya misalnya, dapat memberikan banyak kemudahan bagi pegawai dalam melaksanakan tugas yang dibebankan. Tidak hanya itu, dukungan teknologi informasi juga dapat meningkatkan efisiensi dan efektifitas kerja. Pelaksanaan suatu pekerjaan yang sebelumnya memerlukan waktu yang relatif lama, dengan adanya teknologi informasi pekerjaan tersebut dapat diselesaikan secara lebih cepat dan akurat. Adanya pengaruh teknologi informasi terhadap kinerja pegawai secara empiris sudah banyak dibuktikan oleh peneliti-peneliti sebelumnya. Vozikis et al. (2010) dalam penelitiannya di Yunani menemukan bahwa penggunaan teknologi informasi dapat meningkatkan kinerja pegawai. Temuan yang sama juga disimpulkan dalam penelitian Imran et al. (2014) yang juga menyimpulkan bahwa teknologi informasi berpengaruh posiif dan signifikan terhadap kinerja pegawai.

\section{Keterkaitan antara Komitmen Pelayanan dan Kinerja Pegawai}

Komitmen atau rasa keterikatan pegawai pada organisasi tempat mereka bekerja dapat berdampak pada kinerja pegawai tersebut. Bagi instansi pemerintah yang menyelenggarakan 
layanan publik misalnya, dibutuhkan adanya komitmen pegawai dalam mendukung seluruh pelayanan yang diberikan. Komitmen pelayanan menentukan kesungguhan pegawai dalam melaksanakan tugas yang dibebankan kepada mereka. Ketika pegawai memiliki komitmen pelayanan yang relatif baik, mereka akan termotivasi untuk melaksanakan tugas dengan sebaikbaiknya. Dengan demikian terdapat hubungan searah antara komitmen pelayanan dengan kinerja pegawai. Komitmen pelayanan berpengaruh positif dan signifikan terhadap kinerja pegawai (Rikatta, 2012, Wright \& Bonnet, 2012). Pegawai yang memiliki komitmen yang kuat akan cenderung bekerja serius dan bersungguh-sungguh dalam menyelesaikan pekerjaan yang dibebankan kepada mereka sehingga kinerjanya meningkat (Elmadag et al., 2008). Mengacu pada uraian di atas jelaslah bahwa komitmen pelayanan berhubungan searah dengan kinerja pegawai. Semakin tinggi komitmen pelayanan dalam diri seseorang pegawai instansi pemerintah, akan semakin baik pula kinerjanya. Sebaliknya penurunan komitmen pelayanan dapat berdampak pada penurunan kinerja, karena pegawai dengan komitmen relatif rendah cenderung kurang sungguh-sungguh dalam melaksanakan tugas yang pada gilirannya berdampak buruk pada kinerja mereka.

\section{Metodologi Penelitian}

Penelitian ini dilakukan pada SKPD di jajaran pemerintah Kota Banda Aceh. Objek penelitian berhubungan dengan penerapan prinsip GGG dan keterkaitannya dengan kinerja pegawai, ketersediaan teknologi informasi dan komitmen pelayanan dalam diri pegawai. Populasi penelitian adalah seluruh pegawai yang tersebar pada sejumlah SKPD di jajaran pemerintah kota Banda Aceh. Sampel penelitian dibatasi hanya pada 170 orang pegawai yang diambil dari 17 SKPD yang terpilih sebagai unit analisis.

Kuesioner dengan pertanyaan tertutup merupakan instrumen utama pengumpulan data. Kuesioner tersebut memuat pernyataan yang dikembangkan dari sejumlah indikator pengukuran masing-masing variabel. Implementasi prinsip GGG menggunakan 9 indikator terdiri dari partisipasi, kerangka hukum yang adil, transparansi, responsiveness, berorientasi pada kepentingan masyarakat, equality (kesamaan), efisiensi dan efektifitas dan strategic vision (visi strategis). Kinerja pegawai diukur dengan 5 indikator terdiri dari kualitas hasil kerja, kuantitas penyelesaian pekerjaan, ketepataan waktu, kemandirian, dan komitmen. Teknologi informasi terdiri dari 7 indikator meliputi platform piranti keras komputer, perangkat lunak komputer, aplikasi perangkat lunak instansi, manajemen dan penyimpanan data, platform jaringan/telekomunikasi, platform internet dan layanan konsultasi integrasi sistem. Selanjutnya komitmen pelayanan terdiri dari 5 indikator meliputi kesangggupan mendukung pelayanan, senang mendiskusikan isu-isu yang berkaitan dengan pelayanan publik, berusaha memberikan pelayanan terbaik, ingin meningkatkan kualitas pelayanan dan kepedulian terhadap kualitas pelayanan. Setiap pernyataan disertai dengan pilihan jawaban dalam bentuk tingkat kesetujuan. Pegawai dapat membubuhkan tanda check list ( $\sqrt{ }$ ) pilihan tingkat kesetujuan yang mereka anggap paling sesuai.

Mengingat data yang dianalisis merupakan data kualitatif, maka proses kuantifikasi data agar dapat dianalisis menggunakan model statistik inferensi dilakukan dengan cara memberikan bobot atau skor pada setiap alternatif pilihan tingkat kesetujuan (Amri \& Taharuddin, 2011; Amri, 2012; Ratnawati \& Amri, 2013; Rizal et al., 2015). Pemberian skor menggunakan skala Likert 1 sampai 5 dengan ketentuan skor tinggi poin tinggi dan skor rendah poin rendah. Ketentuan ini berlaku mengingat seluruh indikator pengukuran dikembangkan dalam bentuk pernyataan positif (Amri, 2013; Farnita \& Amri, 2013). Alternatif pilihan tingkat kesetujuan berdasarkan skor dimaksud adalah $1=$ sangat tidak setuju, 2 = tidak setuju, $3=$ ragu-ragu, $4=$ setuju dan 5 = sangat setuju (Amri, 2014; Iskandar \& Amri, 2014).

Selanjutnya alat statistik yang diterapkan untuk menganalisis hubungan antar variabel adalah model statistik multivariat structural equation modelling. Model analisis ini dianggap mampu memberikan hasil estimasi paling akurat dibandingkan model statistik lainnya. Karena uji arah dan signifikansi hubungan antar variabel 
dilakukan secara bersamaan dengan melibatkan seluruh indikator pengukuran dalam setiap tahapan pengujian.

\section{Hasil dan Pembahasan}

Langkah penting penerapan SEM guna menganalisis hubungan antar variabel adalah mengetahui kemampuan indikator pada setiap variabel dalam memanifestasikan variabel tersebut. Suatu indikator dapat dianggap sebagai manifestasi dari variabelnya, ketika indikator tersebut dapat merefleksikan variabel. Dalam SEM, indikator pengukuran suatu variabel juga dilihat sebagai faktor yang merefleksikan variabel yang bersangkutan. Karena itu, kemampuan indikator pengukuran dalam mengkonfirmasi setiap variabelnya, perlu diuji secara statistik sebelum analisis terhadap hubungan antar variabel dilakukan. Uji ini sering disebut dengan confirmatory factor analysis (CFA). Melalui CFA dapat diketahui kemampuan suatu indikator dalam mengkonfirmasi fenomena yang berkaitan dengan yang diukur. Tolok ukur yang digunakan adalah besaran nilai statistik yang diperoleh melalui perhitungan statistik, terdiri dari loading factor $>0,70$, critical ratio $>2,00$ dan $p$-value $<0,05$. Suatu indikator dikatakan mampu mengkonfirmasi variabel, apabila ukuran nilai tersebut terpenuhi. Sebaliknya, apabila suatu indikator memiliki loading factor $<0,70$, critical ratio $<2,00$ dan $p$-value $>0,05$ maka dapat diartikan bahwa indikator tersebut tidak mampu mengkonfirmasi variabelnya.

Confirmatory factor analysis dalam penelitian ini terdiri dari dua tahap. Dalam tahap pertama, terdapat sejumlah indikator dengan nilai statistik belum memenuhi ketentuan di atas, yakni indikator ketujuh berkaitan dengan teknologi informasi (TI7) dengan loading factor sebesar 0,430, indikator kelima dan keenam berkaitan dengan implementasi GGG (GG5 dan GG6)

Tabel 1. Hasil Confirmatory Factor Analysis

\begin{tabular}{|c|c|c|c|c|c|c|c|}
\hline & & \multicolumn{3}{|c|}{ Tabas 1} & \multicolumn{3}{|c|}{ Tabas 2} \\
\hline & & $\begin{array}{l}\text { Loading } \\
\text { Factor }\end{array}$ & $\begin{array}{l}\text { Critical } \\
\text { Ratio }\end{array}$ & p-value & $\begin{array}{l}\text { Loading } \\
\text { Factor }\end{array}$ & $\begin{array}{l}\text { Critical } \\
\text { Ratio }\end{array}$ & p-rake \\
\hline KP1 <--- & Kinerja_Pegawai &, 770 & & &, 769 & & \\
\hline $\mathrm{KP} 2<--$ & Kinerja_Pegawai &, 735 & 9,901 & ****; &, 737 & 9,901 & wok: \\
\hline KP3 <--- & Kinerja_Pegawai &, 787 & 10,725 & **o*k &, 786 & 10,725 & wok: \\
\hline $\mathrm{KP} 4<-$ & Kinerja_Pegawai &, 729 & 9,802 & *kwk &, 733 & 9,802 & **k* \\
\hline KP5 <--- & Kinerja_Pegawai &, 768 & 10,419 & *kok &, 765 & 10,419 & ***; \\
\hline GG9 <--- & Good_Governance &, 739 & & &, 747 & & \\
\hline GG8 <--- & Good_Governance & ,751 & 9,837 & ****; &, 745 & 9,837 & *k** \\
\hline GG7 <-- & Good_Governance &, 797 & 10,491 & ***** & 809 & 10,491 & *ok* \\
\hline GG6 <-- & Good_Governance & ,510 & 6,526 & ****; & & & \\
\hline GG5 <-- & Good_Governance & ,661 & 8,579 & *kmok & & & \\
\hline GG4 <--- & Good_Governance &, 726 & 9,479 & **ok &, 729 & 9,589 & *⿻*:* \\
\hline GG3 <--- & Good_Governance &, 768 & 10,077 & **w* &, 762 & 10,063 & *ok* \\
\hline GG2 <--- & Good_Governance &, 788 & 10,358 & *wok &, 789 & 10,464 & wok* \\
\hline GG1 <--- & Good_Governance &, 725 & 9,468 & $* * * *$ &, 714 & 9,365 & *k*; \\
\hline TI7 <-- & Telnologi_Informasi & ,430 & & & & & \\
\hline TI6 <--- & T'eknologi_Informasi &, 778 & 5,450 & **ak &, 784 & & \\
\hline$<--$ & Teknologi_Informasi &, 745 & 5,373 & **ok &, 740 & 9,985 & *k** \\
\hline TI4 <-- & Teknologi_Informasi &, 728 & 5,331 & *wok &, 733 & 9,871 & **** \\
\hline$<--$ & Teknologi_Informasi &, 745 & 5,374 & ****; &, 739 & 9,977 & **** \\
\hline TT2 <-- & Teknologi_Informasi &, 749 & 5,382 & $* * * *$ &, 747 & 10,094 & **k* \\
\hline TI1 <--- & Teknologi_Informasi &, 802 & 5,501 & *kwk &, 808 & 11,085 & *⿻*k \\
\hline KM5 <--- & Kompel &, 783 & & &, 783 & & \\
\hline $\mathrm{KM} 4<--$ & Kompel &, 779 & 10,485 & **o* &, 779 & 10,481 & *ok* \\
\hline KM3 $<---$ & Kompel &, 763 & 10,232 & ***ok &, 763 & 10,233 & $* * k *$ \\
\hline $\mathrm{KM} 2<--$ & Kompel &, 783 & 10,542 & *k\$k &, 783 & 10,537 & \#k*\% \\
\hline KM1 <--- & Kompel &, 786 & 10,591 & *k*k &, 786 & 10,585 & ok:* \\
\hline
\end{tabular}


dengan loading factor masing-masing sebesar 0,661 dan 0,510. Hal ini mengindikasikan bahwa dari 7 indikator yang digunakan untuk mengukur teknologi informasi, indikator ketujuh tidak mampu merefleksikan variabel persepsi pegawai terhadap ketersediaan teknologi informasi. Selanjutnya, dari 9 indikator yang digunakan untuk mengukur implementasi GGG, indikator kelima dan keenam juga dianggap tidak mampu mengkonfirmasi variabel tersebut. Berkaitan dengan variabel kinerja pegawai dan komitmen pelayanan, seluruh indikator dalam variabel tersebut menghasilkan nilai statistik sesuai dengan yang diharapkan. Tidak satu pun diantara indikator yang memiliki nilai loading factor di bawah 0,70. Kriteria nilai lainnya seperti critical ratio di atas 2,00 dan p-value di bawah 0,05 juga sudah terpenuhi. Hal ini mengindikasikan seluruh indikator yang digunakan untuk mengukur kinerja pegawai mampu mengkonfirmasi kinerja pegawai. Demikian pula halnya dengan indikator yang digunakan dalam mengukur komitmen pelayanan, juga mampu mengkonfirmasi variabel tersebut. indikator juga memiliki nilai critical ratio di atas 2,00 dan p-value di bawah 0,05. Dengan demikian, indikator yang dilibatkan dalam tahapan full structural model SEM adalah seluruh indikator yang sudah dinyatakan memenuhi syarat dalam uji CFA tahap kedua, yakni tanpa melibatkan indikator TI7, GG5 dan GG6.

Setelah uji CFA, langkah kedua dalam penggunaan SEM adalah melakukan uji kesesuaian model (measurement moded). Uji ini diperlukan untuk memastikan bahwa model structural yang disusun untuk menjelaskan hubungan fungsional antara variabel yang diteliti benar-benar cocok dan sesuai dengan kebutuhan estimasi. Ukuran yang sering digunakan adalah sejumlah kriteria goodness of fit, terdiri dari nilai $\mathrm{X}^{2}$ hitung, GFI (Goodness of Fit Index), AGFI (Adjusted Goodness of Fit Index), CFI (Comparative Fit Index), TLI (Tucker Lewis Index) dan Root Mean Square Error of Approximation (RMSEA). Model pengukuran dinyatakan memenuhi syarat jika hasil perhitungan statistik menghasilkan nilai $\mathrm{X}^{2}$ hitung relatif kecil, p-value $>0,05$, GFI $>0,90$, AGFI $>0,90$, CFI $>0,95$, TLI $>0,95$ dan RMSEA $<0,08$. Jika ketentuan tersebut belum terpenuhi, maka model belum bisa dinyatakan baik (fit).

Tabel 2. Hasil Measurement Model

\begin{tabular}{|c|c|c|c|c|c|}
\hline \multirow{2}{*}{$\begin{array}{c}\text { Goodness-of-Fit } \\
\text { Index }\end{array}$} & \multirow{2}{*}{$\begin{array}{c}\text { Kriteria } \\
\text { Nilai }\end{array}$} & Hasil Statistik & $\begin{array}{c}\text { Evaluasi } \\
\text { Model }\end{array}$ & Hasil Statistik & $\begin{array}{c}\text { Evaluasi } \\
\text { Model }\end{array}$ \\
\cline { 3 - 6 }$\chi^{2}$ - Chi-square & $\begin{array}{c}\mathrm{X}_{\text {hit }}^{2}<\mathrm{X}^{2} \\
\text { tab }\end{array}$ & $692,279>361,65$ & Belum Baik & $201,958<259,914$ & Baik \\
\hline Probability & $\geq 0,05$ & 0,000 & Belum Baik & 0,087 & Baik \\
\hline GFI & $\geq 0,90$ & 0,779 & Belum Baik & 0,945 & Baik \\
\hline AGFI & $\geq 0,90$ & 0,739 & Belum Baik & 0,937 & Baik \\
\hline CFI & $\geq 0,95$ & 0,865 & Belum Baik & 0,965 & Baik \\
\hline TLI & $\geq 0,95$ & 0,852 & Belum Baik & 0,957 & Baik \\
\hline RMSEA & $\leq 0,08$ & 0,082 & Belum Baik & 0,065 & Baik \\
\hline
\end{tabular}

Sumber : Data Primer (Diolah), 2020.

Mengingat dalam uji CFA tahap pertama terdapat sejumlah indikator dengan nilai loading factor di bawah 0,05 , maka indikator tersebut direduksi dari model persamaan. Kemudian dilakukan uji CFA tahap kedua tanpa melibatkan ketiga indikator yang telah direduksi tersebut. Hasil CFA tahap pertama dan kedua seperti ditunjukkan dalam Tabel 1. Tabel 1 memperlihatkan bahwa pada uji CFA tahap kedua, semua indikator sudah memiliki nilai loading factor di atas 0,70. Masing-masing
Sejalan dengan tahapan uji CFA, uji measurement model juga terdiri dari dua tahap. Pada tahap pertama, diperoleh $\mathrm{X}^{2}$ hitung sebesar 692,279. Angka ini lebih besar dibandingkan dengan nilai $\mathrm{X}^{2}$ hitung $(\mathrm{df}=319)$ sebesar 361,65. Artinya kriteria yang ditentukan belum terpenuhi, sehingga berdasarkan nilai $\mathrm{X}^{2}$ dapat diartikan bahwa pada tahap pertama, model pengukuran belum bisa dikatakan baik. Kriteria lainnya seperti $p$-value, GFI, AGFI, CFI, TLI dan

44 | Jurnal Ekonomi dan Manajemen Teknologi Vol. 4 | No. 1 | 2020 
RMSEA juga belum terpenuhi. Untuk lebih jelasnya mengenai measurement model dapat dilihat Tabel 2.

Pada uji tahap kedua, seluruh kriteria sudah terpenuhi dengan baik. Seperti ditunjukkan dalam tabel 2 diatas, hasil pengujian statistik menghasilkan nilai $\mathrm{X}^{2}$ hitung sebesar 201,958. Angka ini lebih kecil dibandingkan dengan nilai $\mathrm{X}^{2}$ hitung $(\mathrm{df}=224)$ sebesar 259,91 . Nilai $\mathrm{p}-$ value sebesar 0,087 juga lebih besar dari 0,05 sebagai nilai minimum yang dipersyaratkan. Selanjutnya kriteria lainnya seperti GFI dan AGFI masing-masing lebih besar dari 0,90, dan nilai CFI dan TLI lebih besar dari 0,95 juga sudah terpenuhi. Demikian juga halnya dengan RMSEA juga sudah menghasilkan nilai statistik yang diinginkan yakni sebesar 0,065 lebih kecil dari 0,08 .

Setelah uji CFA dan measurement model, langkah ketiga dalam penggunaan SEM adalah menguji hubungan antar variabel secara keseluruhan (full structural mode). Menggunakan software AMOS 21, hasil full structural model yang menjelaskan keterkaitan antar variabel dideskripsi dalam gambar/skema dan angkaangka statistik. Hubungan fungsional antara kinerja pegawai dan implementasi GGG dengan teknologi informasi dan komitmen pelayanan dalam bentuk skema seperti ditunjukkan dalam Gambar 1.
Konsisten dengan Gambar 1 di atas, maka koefisien estimasi yang secara statistik menginformasikan agar dan signifikansi pengaruh antar variabel ditunjukkan dalam Tabel 3.

\section{Tabel 3. Koefisien Estimasi}

\begin{tabular}{|c|c|c|c|c|c|}
\hline & & & $\begin{array}{c}\text { Koefisien } \\
\text { Estimasi }\end{array}$ & $\begin{array}{c}\text { Critical } \\
\text { Ratio }\end{array}$ & $\mathrm{p}$-value \\
\hline Komitmen pelayanan & $\cdots>$ & Implementasi GGG & $0,346 * *$ & 4,299 & 0,001 \\
\hline Teknologi informasi & $\cdots>$ & Implementasi GGG & $0,450 * *$ & 5,336 & 0,001 \\
\hline Implementasi GGG & $\cdots$ & Kinerja_Pegawwai & $0,718 * *$ & 8,409 & 0,001 \\
\hline Teknologi Informasi & $\cdots>$ & Kinerja_Pegawai & $0,184 * *$ & 6,563 & 0,001 \\
\hline Komitmen pelayanan & $\cdots>$ & Kinerja_Pegawai & $0,150^{*}$ & 3,784 & 0,021 \\
\hline
\end{tabular}

Sumber : Data Primer (Diolah), 2020

*) signifikan pada keyakinan $95 \%,{ }^{* *}$ ) signifikan pada keyakinan $99 \%$.

Mengacu pada tabel 3 di atas terlihat bahwa teknologi informasi berpengaruh positif secara nyata terhadap implementasi prinsip GGG. Hal ini ditunjukkan oleh koefisien estimasi sebesar 0,450 dengan $\mathrm{p}$-value sebesar 0,001. Semakin baik kualitas teknologi informasi semakin baik implementasi prinsip GGG dilingkungan pemerintah kota Banda Aceh. Sebaliknya, penurunan kualitas teknologi informasi secara signifikan berdampak pada penurunan implementasi prinsip GGG. Sehingga terdapat hubungan searah antara kedua variabel tersebut. Temuan ini sejalan dengan hasil penelitian empiris yang dilakukan oleh Trakulmututa \& Chaijareonwattana (2013) yang juga memberikan bukti empiris bahwa implementasi prinsipprinsip tata pemerintahan yang baik secara signifikan dipengaruhi oleh penggunaan teknologi informasi.

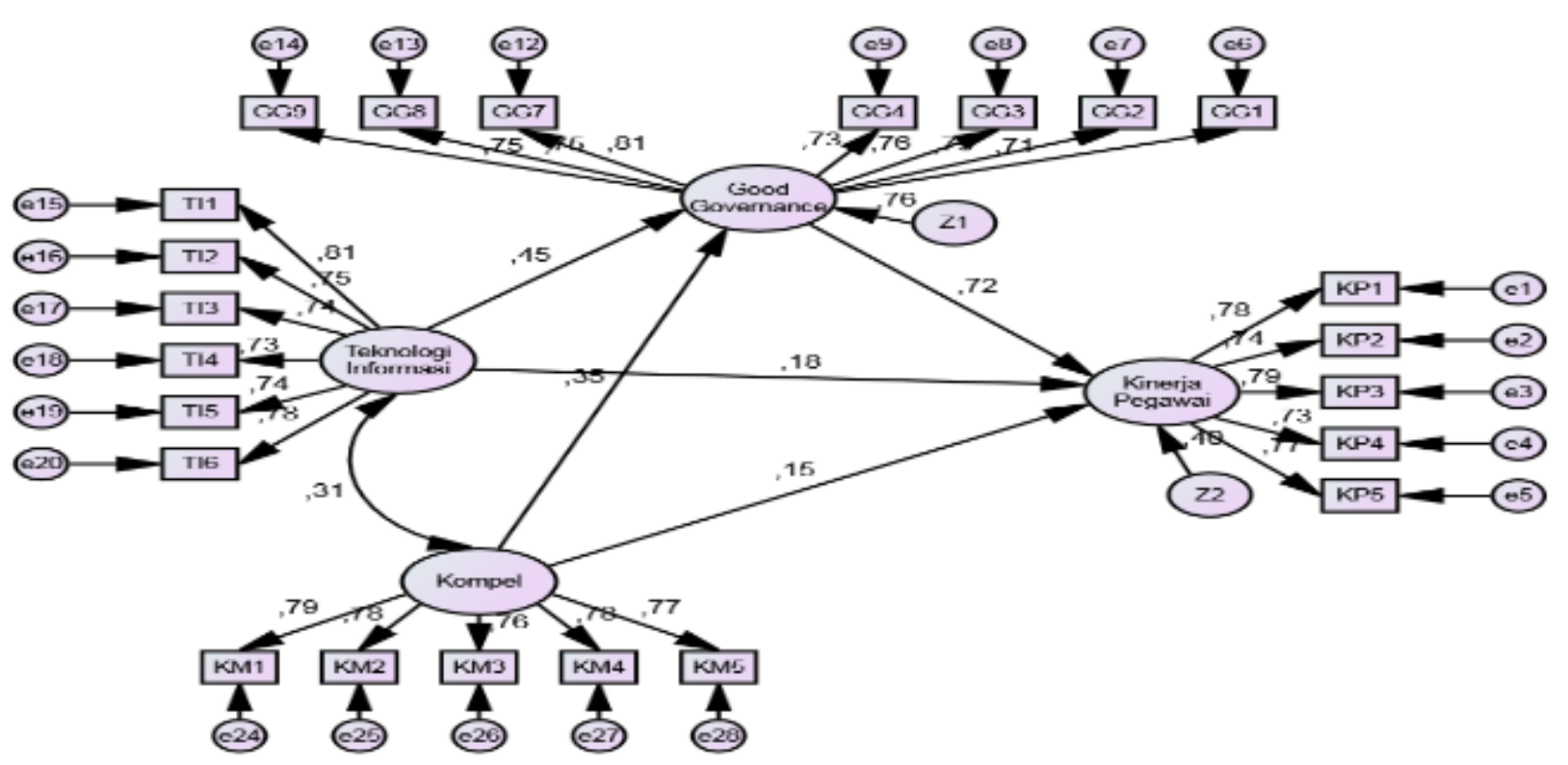

Gambar 1. Skema Hasil Hubungan antar Variabel 
Teknologi informasi juga secara positif dan signifikan berpengaruh terhadap kinerja pegawai dengan koefisien estimasi 0,718 dan $p$ value sebesar 0,001. Peningkatan teknologi informasi secara nyata berdampak pada peningkatan kinerja pegawai. Sehingga arah hubungan antara ketersediaan teknologi informasi yang berkualitas dan memenuhi kebutuhan pelaksanaan pekerjaan di satu sisi, dengan peningkatan kinerja pegawai di sisi lain juga positif. Temuan ini konsisten dengan hasil penelitian. Semakin baik teknologi informasi semakin baik pula kinerja pegawai instansi pemerintah dilingkungan pemerintah kota Banda Aceh. Adanya hubungan searah antara kedua variabel tersebut mengkonfirmasi temuan penelitian Vozikis et al. (2010) di Yunani dan hasil penelitian empiris yang dilakukan Imran et al. (2014) pada sejumlah perusahaan perbankan di Pakistan yang juga membuktikan adanya pengaruh positif teknologi informasi terhadap kinerja pegawai.

Tabel 3 juga memperlihatkan koefisien estimasi komitmen pelayanan terhadap implementasi prinsip GGG sebesar 0,346, dan terhadap kinerja pegawai sebesar 0,150. Nilai p-value masing-masing koefisien estimasi tesebut sebesar 0,001 dan 0,021. Hal ini berarti bahwa komitmen pelayanan juga berpengaruh positif layanan publik, semakin baik pula implementasi prinsip GGG dan hasil kerja yang mampu mereka capai. Adanya hubungan searah antara komitmen pelayanan dengan implementasi prinsip GGG mendukung temuan Trakulmututa \& Chaijareonwattana (2013) yang menyimpulkan bahwa komitmen dan kesungguhan pegawai dalam menyelenggarakan tugas pelayanan publik menjadi faktor kunci keberhasilan implementasi good government governance. Selanjutnya, temuan ini yang membuktikan adanya pengaruh positif dan signifikan komitmen pelayanan terhadap kinerja pegawai sejalan dengan hasil kajian Wright \& Bonnet (2012) yang juga mengungkapkan bahwa komitmen pelayanan berpengaruh secara nyata terhadap peningkatan kinerja pegawai. Temuan ini juga mengkonfirmasi hasil penelitian empiris yang dilakukan Elmadag et al. (2008) yang membuktikan bahwa pegawai dengan komitmen yang tinggi memiliki kesungguhan dalam bekerja dan mampu menghasilkan kualitas hasil kerja yang lebih baik dibandingkan dengan pegawai berkomitmen rendah.

Implementasi prinsip GGG juga berpengaruh positif dan signifikan terhadap kinerja pegawai dilingkungan pemerintah kota Banda Aceh. Hal ini ditunjukkan oleh koefisien estimasi sebesar 0,718 dengan $p$-value sebesar 0,001. Semakin baik implementasi GGG semakin baik pula kinerja pegawai. Sebaliknya, penurunan implementasi

Tabel 4. Pengaruh Langsung dan Tidak Langsung antar Variabel

\begin{tabular}{|c|c|c|c|c|c|}
\hline & & & & $\begin{array}{l}\text { Koefisien } \\
\text { Estimasi }\end{array}$ & $\begin{array}{c}\text { Besar } \\
\text { Pengaruh }\end{array}$ \\
\hline Komitmen pelayanan & $\cdots>$ & $\begin{array}{l}\text { Implementasi } \\
\text { GGG }\end{array}$ & & 0,346 & $11,97 \%$ \\
\hline Teknologi informasi & $\cdots$ & $\begin{array}{l}\text { Implementasi } \\
\text { GGG }\end{array}$ & & 0,450 & $20,25 \%$ \\
\hline Implementasi GGG & $\cdots$ & Kinerja Pegawai & & 0,718 & $51,55 \%$ \\
\hline Teknologi Informasi & $\cdots$ & Kinerja Pegawai & & 0,184 & $3,39 \%$ \\
\hline Komitmen pelayanan & $\cdots>$ & Kinerja Pegawai & & 0,150 & $2,25 \%$ \\
\hline Komitmen pelayanan & $\cdots>$ & $\begin{array}{l}\text { Implementasi } \\
\text { GGG }\end{array}$ & ---> Kinerja Pegawai & $0,346 * 0,718$ & $24,84 \%$ \\
\hline Teknologi Informasi & $-\cdots>$ & $\begin{array}{l}\text { Implementasi } \\
\text { GGG }\end{array}$ & $--->$ Kinerja Pegawai & $0,450 * 0,718$ & $32,31 \%$ \\
\hline
\end{tabular}

Sumber: Data primer (Diolah), 2020.

secara nyata terhadap implementasi prinsip GGG dan kinerja pegawai. Semakin baik komitmen pegawai dalam menyelenggarakan prinsip good governance tersebut, berdampak buruk pada penurunan kinerja pegawai. Hasil SEM di atas menginformasikan bahwa pengaruh teknologi informasi dan komitmen pelayanan terhadap kinerja pegawai dilingkungan 
pemerintah kota Banda Aceh tidak hanya terjadi secara langsung, tetapi juga secara tidak langsung melalui implementasi prinsip GGG sebagai variabel perantara. Mengacu pada nilai koefisien estimasi seperti dalam tabel di atas, maka pengaruh langsung (direct effect) dan tidak langsung (indirect effect) antar variabel seperti ditunjukkan dalam Tabel 4.

Pengaruh langsung teknologi informasi dan komitmen pelayanan terhadap implementasi GGG masing-masing sebesar 11,97\% dan $20,25 \%$. Hal ini mengindikasikan bahwa dampak teknologi informasi dalam mendukung perbaikan implementasi GGG di jajaran pemerintah kota Banda Aceh lebih besar dibandingkan dengan dampak komitmen pelayanan. Sehingga keberadaaan teknologi informasi merupakan suatu hal yang sangat penting guna mewujudkan tata pemerintahan yang baik. Kendatipun pegawai memiliki komitmen dan kesungguhan yang tinggi dalam melaksanakan tugas pelayanan publik, namun tanpa adanya dukungan teknologi informasi, upaya implementasi GGG tetap menjadi terkendala.

Teknologi informasi dan komitmen pelayanan juga berpengaruh secara langsung terhadap kinerja pegawai. Dalam hal ini, pengaruh langsung teknologi informasi sebesar 3,39\% lebih besar dibandingkan dengan pengaruh langsung komitmen pelayanan sebesar 2,25\%. Hasil ini memperkuat bukti bahwa eksistensi teknologi informasi memiliki peran dominan dalam mendukung keberhasilan pelaksanaan pekerjaan oleh para pegawai. Tanpa dukungan teknologi informasi yang memenuhi kebutuhan mereka dalam bekerja, maka kesungguhan dalam menyelesaikan tugas belum dapat memberikan hasil yang signifikan bagi perbaikan kinerja mereka.

Tabel 4 juga memperlihatkan bahwa pengaruh tidak langsung teknologi informasi terhadap kinerja pegawai dilingkungan pemerintah kota Banda Aceh sebesar 32,31\%, jauh lebih besar dibandingkan dengan pengaruh langsung variabel tersebut sebesar 3,39\%. Hal ini secara statistik mengindikasikan bahwa keberadaan implementasi GGG sebagai variabel perantara memperkuat pengaruh teknologi informasi terhadap kinerja pegawai. Pengaruh tidak langsung komitmen pelayanan terhadap kinerja pegawai melalui implementasi GGG sebesar $24,84 \%$, jauh lebih besar dibandingkan dengan pengaruh tidak langsung variabel tersebut sebesar 2,25\%. Hasil ini mengisyaratkan bahwa implementasi GGG juga dapat memediasi pengaruh komitmen pelayanan terhadap upaya peningkatan kinerja pegawai dilingkungan pemerintah tersebut.

\section{Simpulan}

Teknologi informasi dan komitmen pelayanan berpengaruh terhadap implementasi prinsipprinsip GGG dan kinerja pegawai dilingkungan Pemerintah Kota Banda Aceh. Semakin baik teknologi informasi dan semakin tinggi komitmen pegawai dalam menyelenggarakan pelayanan publik, semakin baik implementasi GGG dan kinerja pegawai. Sebaliknya, ketika teknologi informasi kurang baik dan komitmen pelayanan menurun, maka implementasi prinsipprinsip GGG dan kinerja pegawai juga akan menurun. Selanjutnya implementasi prinsip GGG berdampak positif terhadap kinerja pegawai. Pengaruh teknologi informasi dan komitmen pelayanan terhadap kinerja pegawai tidak hanya terjadi secara langsung, tetapi melalui implementasi prinsip GGG. Keberadaan prinsip GGG sebagai variabel pemediasi memperkuat teknologi informasi dan komitmen pelayanan terhadap kinerja pegawai. Efek mediasi yang ditimbulkan oleh prinsip GGG adalah mediasi parsial.

Merujuk pada kesimpulan tersebut, maka upaya peningkatan implementasi prinsip GGG dan kinerja pegawai dapat dilakukan melalui intervensi kebijakan yang berhubungan dengan perbaikan teknologi informasi dan peningkatan komitmen pegawai dalam menyelenggarakan pelayanan publik. Karena itu, kepala SKPD dijajaran pemerintah kota Banda Aceh perlu memberikan perhatian yang lebih baik terhadap kualitas teknologi informasi yang selama ini digunakan dan meningkatkan komitmen pegawai dalam meningkatkan kualitas pelayanan publik.

\section{Ucapan Terima Kasih}

Penulis menyampaikan terima kasih yang 
sebesar-besarnya kepada Deputi Bidang Penguatan Riset dan Pengembangan Kementerian Riset dan Teknologi/Badan Riset dan Inovasi Nasional sebagai penyandang dana penelitian pada skema Penelitian Dosen Pemula (PDP) Tahun 2020. Rasa terima kasih juga penulis haturkan kepada LPPM STMIK Indonesia Banda Aceh yang telah menfasilitasi para dosen dalam memperoleh dana hibah penelitian.

\section{Daftar Pustaka}

Ahmad, L., \& Wali, M. (2019). Perancangan software asisten dosen sebagai media dalam pelaksanaan computer assisted learning di AMIK Indonesia Banda Aceh. Smart Comp: Jurnalnya Orang Pintar Komputer, 8 (1), 38-43.

Ali, N. N. K., \& Tang, S. Y. (2016). Does Multiple Leadership Styles Mediated By Job Satisfaction Influence Better Business Performance? Perception Of Mnc Employees In Malaysia, SHS Web of Conferences, 23, 2-16.

Amri, K. (2012). Faktor-faktor yang mempengaruhi kepercayaan pengguna layanan perawatan kecantikan, Jurnal Manajemen dan Keuangan, 1(1), 10-21.

Amri, K. (2013). Faktor-faktor yang mempengaruhi loyalitas konsumen surat kabar Harian Serambi Indonesia di kota Banda Aceh. Jurnal Ekonomi Manajemen dan Bisnis, 1 (1), 229-242

Amri, K. (2014). Pengaruh kemampuan kerja, komunikasi, kekompakkan tim kerja dan kepemimpinan terhadap kualitas laporan hasil pemeriksaan Inspektorat Aceh. Jurnal Ilmiah Manajemen Muhammadiyah, 2(2).

Amri, K. (2015). Pengaruh perilaku kepemimpinan dan motivasi dalam meningkatkan produktivitas kerja karyawan PT Bank Sinarmas Tbk cabang Banda Aceh, Jurnal Ekonomi Manajemen dan Bisnis, 3(1), 522-536.
Amri, K., \& Taharuddin. (2011). Sensitivitas respon konsumen terhadap merek, Jurnal Samudra Ekonomi dan Bisnis, 2(2), 114137.

Barna, G. (2010). Menumbuhkan Murid-Murid Sejati, Metanoia Publishing, Jakarta.

Dwiyanto, A. (2016). Mewujudkan Good Geovernance Melalui Pelayanan Publik, UGM Press. Yogyakarta.

Elmadag, A. B., Ellinger, A. E., \& Franke, G. R. (2008). Antecedents and consequences of frontline service employee commitment to service quality. Journal of Marketing Theory and Practice, 16(2), 95-110.

Farnita, I., \& Amri, K. (2013). Persepsi mahasiswa terhadap kualitas layanan Pendidikan Akademi Manajemen Informatika dan Komputer Indonesia (AMIKI) Banda Aceh. Jurnal Ekonomi Manajemen dan Bisnis 1 (1), 118-139

Imran, M., Maqbool, N., \& Shafique, H. (2014). Impact of Technological Advancement on Employee Performance in Banking Sector, International Journal of Human Resource Studies, 4(1), 57-70.

Iskandar, D., \& Amri, K. (2014). Pengaruh daya Tarik iklan, kualitas pesan iklan dan frekuensi penayangan iklan terhadap efektivitas iklan televisi produk mie instan merek Indomie Goreng Cabe Ijo, Jurnal Ekonomi Manajemen dan Bisnis, 2(1), 424-437.

Ratnawati \& Amri, K. (2013). Pengaruh keadilan organisasional, kepercayaan pada atasan terhadap perilaku kewargaan organisasi (organizational citizenship behavior). Jurnal Ekonomi Manajemen dan Bisnis, 1(1), 56-73.

Rikatta, M. (2012). Attitudinal organizational commitment and job performance: A meta-analysis, Journal of Organizational Behavior, 23, 257-266. 
Rivai, V., \& Sagala (2009), Performance Appraisal, Penerbit : PT. Raja Grafindo Persada, Jakarta.

Rizal, S., Sarboini, Wali, M., \& Masitah. (2015). The effect of leadership style, compensation and organizational commitment to working satisfaction of Aceh social service employees. Journal of Applied Economic Sciences, 14 (3(65)), 797-803

Trakulmututa, J., \& Chaijareonwattana, B. (2013) Factors Affecting the Achievement of Good Governance in HRM: The Empirical Study of Local Governments in Southern Part of Thailand, International Journal of Business and Social Science, 4(7), 34-39.
Vozikis, A., Yofanti, M., \& Papadopoulas, I. (2010). Attitudes Towards The Use Of Information And Communication Technologies (ICT) at Work: Findings From The Health Care Sector In Greece, Spoudai, 60(1-2), 82-96.

Weill, P. and Ross, J. W. (2016). IT Governance: How Top Performance Manage It Decision Rights For Superior Result. Harvard Business School Pres. Boston.

Wright, T. A., \& Bonnett, D. G. (2012). The moderating effects of employee tenure on the relation between organizational commitment and job performance: A metaanalysis. Journal of Applied Psychology, 87(6), 1183-1190. 